\title{
HOT AQUEOUS SOLUTIONS FOR THE QUENCHING OF STEELS
}

\author{
By H. J. French and T. E. Hamill
}

\section{ABSTRACT}

Surface and center cooling curves are given for small cylinders of high-carbon steel quenched in water, sodium hydroxide, sodium-chloride solutions, and oils at different temperatures. The characteristics of these cooling curves and a study of the hardnesses and structures produced suggested the possibility of using some of the hot aqueous solutions to bridge the gap between the cooling rates obtained with water and oils at atmospheric temperatures. Experiments with carbon and alloy steel tensile test specimens and gages seemed to justify the view that hot aqueous solutions can provide a useful group of coolants with graded cooling characteristics for the hardening of small steel pieces. Suggestions for further work are also given.

\section{CONTENTS}

II. Methods of test used

III. Results of the tests_._.

1. Center and surface cooling curves_._._._. 401

2. Hardness and structures produced by the different coolants_- 406

3. Liquids with graded cooling speeds _._.

4. Tensile properties produced by the hot aqueous solutions_- 410

5. Dimensional changes in the hot aqueous solutions....... 413

IV. Summary

V. Acknowledgments._._. 418

\section{INTRODUCTION}

The experiments described in this report relate to the effect of temperature on the cooling properties of liquids widely used in the hardening of steels and comprise part of a general study of quenching which has been in progress for some time. The results previously reported have related to the properties and structures produced in carbon steels by different coolants at ordinary temperatures, ${ }^{1}$ the effects of initial temperature and mass on center cooling, ${ }^{2}$ the characteristics of center cooling curves, ${ }^{3}$ and a study of the surface cooling of steels in quenching, ${ }^{4}$ but little attention was given in these investiga-

1 H. J. French and O. Z. Klopsch, Quenching Diagrams for Carbon Steels in Relation to Some Quenching Media for Heat Treatment, Trans. Am. Soc. Steel Treating, 3, p. 251; 1924.

${ }^{2}$ H. J. French and O.Z. Klopsch, Initial Temperature and Mass Effects in Quenching, B. S. Tech. Paper No. 295; Trans. Am. Soc. Steel Treating, 9, p. 33; 1926.

${ }^{3}$ H. J. French and O. Z. Klopsch, Characteristics of Quenching Curves, B. S. Tech. Paper, No. 313.

${ }_{4}$ H. J. French, G. S. Cook, and T. E. Hamill, Surface Cooling of Steels in Quenching, Trans. Am. Soc. Steel Treating, 15, p. 217; 1929. 
tions to the effects of coolant temperatures on the manner of cooling or the properties of the quenched steels.

This subject is of interest from several points of view. More information than is now available might point the way to further useful applications of different liquids and should help to establish the limits within which coolant temperatures should be controlled for uniform results; it should also serve to place the time-temperature relations, when quenching steels in hot liquids, upon a firmer foundation.

It is true that much is already known of the effects of temperature upon the coolants now ordinarily used in commercial heat treatment, but this information is of a general nature and based largely upon the properties and structures produced in different steels and the cooling characteristics at the interior of metal bodies. Quantitative information is lacking on the manner of cooling at the surfaces of steel bodies immersed in liquids at different temperatures, and it is the purpose of this report to present such data and a correlation of surface and center cooling with the properties and structures produced in steels.

As early as 1873 Caron ${ }^{5}$ used water at $55^{\circ} \mathrm{C}$. for the quenching of steel springs for hair triggers in rifles and obtained quite as good results as those obtained by more energetic quenching followed by tempering. He also used boiling water for the quenching of 0.2 to 0.4 per cent carbon steels to increase their tensile strength without altering their hardness.

\section{METHODS OF TEST USED}

The experimental methods already described ${ }^{6}$ were used in the tests and the steel cylinders, one-half inch in diameter and 2 inches in length, were all quenched from $875^{\circ} \mathrm{C}$. into coolants moving at 3 feet per second. The test cylinders were made of 0.96 per cent carbon steel having the chemical composition reported in Table 1.

TABLE 1.-Chemical composition of the test cylinders

[Steel C 41]

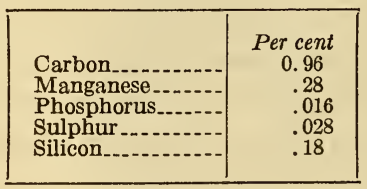

Washington City tap water was used in the water-quenching baths and in the preparation of the sodium-chloride brines and the sodium-

\footnotetext{
SE. Hitzel, Tempering by Warm Water and the Works of Lieutenant-Colonel Caron, Revue de Metallurgie Memoires, 12, p. 584; 1915.

6 See footnotes 1 and 4, p. 399 .
} 
hydroxide solutions. The two latter solutions were made, respectively, with ordinary table salt and technical sodium hydroxide, containing 96 per cent $\mathrm{NaOH}, 2$ per cent $\mathrm{Na}_{2} \mathrm{CO}_{3}, 2$ per cent $\mathrm{NaCl}$, and 2 per cent moisture. The concentrations referred to in this report are weight percentages, and the quenching was carried out in freshly prepared solutions.

Oil No.2, which was used in a majority of the oil-quenching experiments, is a proprietary product and the same oil which was used in earlier experiments. ${ }^{7}$ Its properties were approximately as follows: Specific gravity at $15^{\circ} \mathrm{C}$., 0.874 ; flash point, $190^{\circ} \mathrm{C}$; fire point, $212^{\circ} \mathrm{C}$.; initial boiling point, $375^{\circ} \mathrm{C}$.; final boiling point, which is the equilibrium boiling temperature as determined in a reflux flask under atmospheric pressure, $375^{\circ} \mathrm{C}$.; and final vapor temperature in the determination of the boiling points, $345^{\circ} \mathrm{C}$. The exact composition of this oil is not now known, but analysis indicated that it is probably a mixture of a naphthene base (mineral) oil and about 3.3 per cent fatty oil.

Oil No. 1 is another proprietary quenching oil and its selection for a few experiments was due to its reported ability to cause rapid cooling at high temperatures. This oil consists of a mixture of a small amount of a heavy Pennsylvania residuum oil of high flash point with a special distilled Pennsylvania stock of low flash point. Its properties were as follows: Specific gravity at $15^{\circ} \mathrm{C} ., 0.867$; flash point, $193^{\circ} \mathrm{C}$.; fire point, $216^{\circ} \mathrm{C}$.; initial and final boiling points (reflux method), $380^{\circ} \mathrm{C}$.; final vapor temperature in the determination of the boiling points, $355^{\circ} \mathrm{C}$.

The reported values of hardness for the surfaces of the quenched cylinders are based on 10 tests along the length of the cylinder in the area meeting the direct flow of the liquid. The tests were made after removing about 0.005 inch of the metal from the surface by wet grinding to form narrow flat bands along the length of the cylinders. Center hardness was determined from three tests after cutting the cylinders in half under water spray.

\section{RESULTS OF THE TESTS}

\section{CENTER AND SURFACE COOLING CURVES}

Figures 1, 2, and 3 show the center and surface cooling of the steel cylinders immersed in water, No. 2 oil, 5 per cent sodium-hydroxide and 5 per cent sodium-chloride solutions at temperatures between $20^{\circ}$ and approximately $100^{\circ} \mathrm{C}$. Data for the No. 1 oil are given in Figure 9.

The highest coolant temperature, for water and the aqueous solutions, is given as $99.5^{\circ} \mathrm{C}$. The practice employed was to heat the bath to $100^{\circ} \mathrm{C}$., then remove the source of heat, and transfer the 
tank containing the heated liquid to the quenching apparatus described in reports already referred to. Based on observations with the water baths, it was assumed that the average temperature drop in handling the different aqueous solutions was about $0.5^{\circ} \mathrm{C}$., and the specified temperature, $99.5^{\circ} \mathrm{C}$., merely indicates that the coolant temperature was slightly below the boiling point of water.

Figures 1, 2, 3, 4, and 9 show that increase in the temperature lowered the cooling rates and increased the cooling times in water and the two aqueous solutions while opposite effects were produced in center cooling by the two oils. The changes were small in the oils

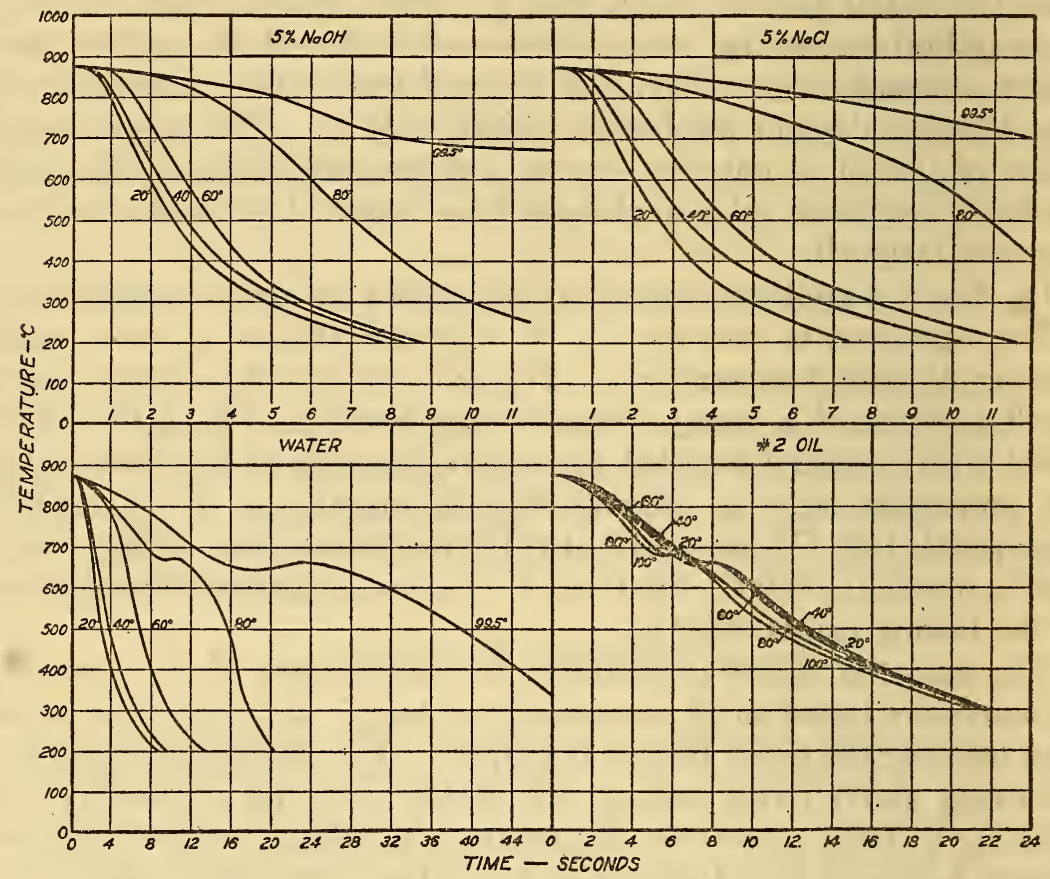

Figure 1.-Center cooling curves of 0.96 per cent carbon steel cylinders quenched from $875^{\circ} \mathrm{C}$. into liquids at different temperatures

Coolant motion was 3 feet per second; cylinders were one-half inch diameter by 2 inches long. Each curve is the average of two or three tests.

throughout the entire temperature range studied $\left(20^{\circ}\right.$ to $100^{\circ} \mathrm{C}$.), and were not as marked between $20^{\circ}$ and $60^{\circ} \mathrm{C}$. in the water and aqueous solutions as between $60^{\circ}$ and $99.5^{\circ} \mathrm{C}$. Also, the changes in cooling times with increase in the coolant temperature were smaller in 5 per cent sodium hydroxide than in 5 per cent sodium chloride and, with the exception of the range $80^{\circ}$ to $99.5^{\circ} \mathrm{C}$., were smaller in 5 per cent sodium chloride than in tap water. (Fig. 4.)

The fact that temperature increase of the coolant affects the cooling in 5 per cent sodium hydroxide somewhat less than in water may be of distinct advantage in practical heat treatment, and probably con- 
tributes in an appreciable degree to the rapidity of cooling in the sodium-hydroxide solution. In all quenching operations the liquid adjacent to the heated steel is raised in temperature even though it is only momentarily in contact with the heated metal surfaces. At least a part of the cooling of the steel is effected through contact with heated liquid and the vapors formed by or released from it.

In liquids which normally decrease in cooling speeds with rise in temperature a small temperature effect, as in the sodium hydroxide, means a tendency to maintain rapid cooling as well as ability to compensate for deficiencies in circulation which usually tend to raise the

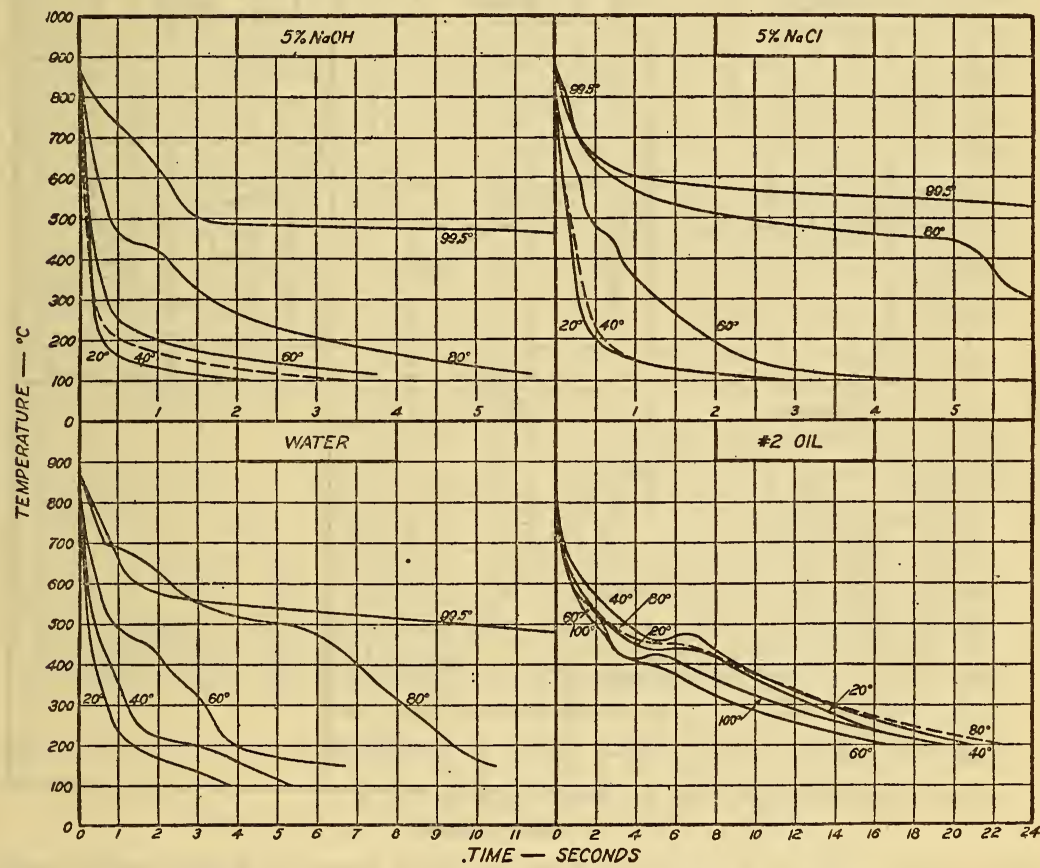

FIgURE 2.-Surface cooling curves of 0.96 per cent carbon steel cylinders quenched from $875^{\circ} \mathrm{C}$. into liquids at different temperatures

Coolant motion was 3 feet per second; cylinders were one-half inch diameter by 2 inches long.

Each curve is the average of two or three tests at a point meeting the direct flow of the liguid.

effective temperature of the quenching bath. From, this viewpoint the 5 per cent sodium hydroxide is a more desirable coolant than water.

Figures 1 and 3 show that the center cooling of specimens immersed in water at $80^{\circ}$ or $99.5^{\circ} \mathrm{C}$. was somewhat more rapid at low temperatures around $200^{\circ}$ to $300^{\circ} \mathrm{C}$. than at high temperatures around $700^{\circ}$ to $800^{\circ} \mathrm{C}$. A similar condition was observed in 5 per cent sodium hydroxide at $99.5^{\circ} \mathrm{C}$., but not at $80^{\circ} \mathrm{C}$. nor in 5 per cent sodium chloride at $80^{\circ}$ or $99.5^{\circ} \mathrm{C}$; in the last three cases the cooling rates were quite regular throughout the temperature range, $850^{\circ}$ to $200^{\circ} \mathrm{C}$. In general, 
these center cooling characteristics were a reflection of the conditions at the surface, although the surface cooling became somewhat more irregular as the temperature of the aqueous solutions approached the boiling point of water.

Rapid cooling of the steel specimens at low temperatures in hot water and the hot aqueous solutions is well recognized and is usually considered to be disadvantageous, since steels are least able to deform without cracking at temperatures around $300^{\circ} \mathrm{C}$., and so relieve the stresses accompanying the volume changes in hardening.

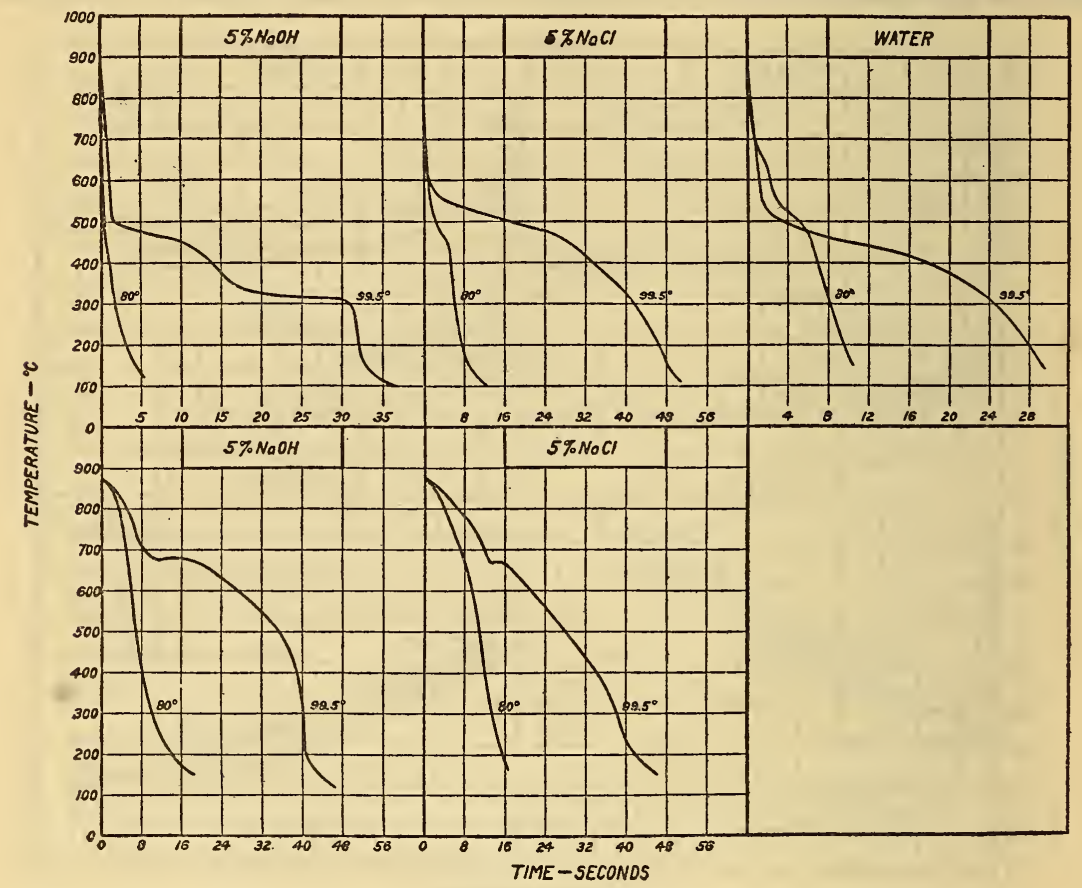

FIGURE 3.-Replot of center and surface cooling curves in liquids at $80^{\circ}$ and and $99.5^{\circ} \mathrm{C}$. shown in part in Figures 1 and 2

Surface cooling shown in top row, center cooling in bottom row.

However, it is difficult to see how the rapid cooling in hot water could, by itself, cause great difficulty, since the cooling rates are less than those obtaining in cold water, cold brines, and sodium-hydroxide solutions in which such difficulties are not important enough to prohibit their use in practical heat treatment. It seems more probable that the danger of cracking in hot water quenching is due to lack of uniform conditions over the surface of the steel during fairly rapid cooling at low temperatures. Evidence of nonuniformity was shown in the original records of the cooling curves, but a much better picture of this situation was obtained by watching and listening to the actual quenching operation. 
As the initial temperature of the water bath is increased, somewhat less heat must be taken from the steel to form steam, and it is not unreasonable to assume that more steam will come in contact with, or become attached to, the surfaces of the metal in a given time. As has already been shown ${ }^{8}$ such conditions promote nonuniform cooling, since the action at the contact surfaces between the metal and the coolant, or their products, is probably made up primarily of rapidly

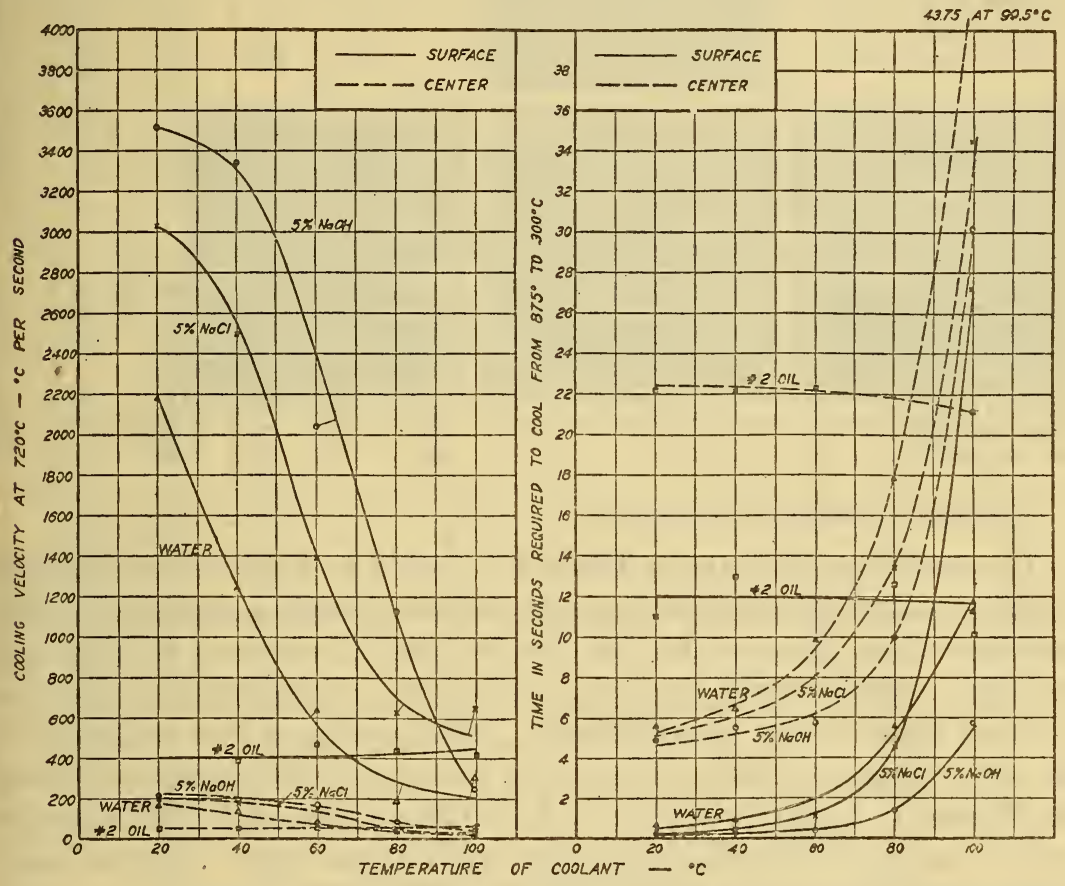

Figure 4.-Effect of temperature on center and surface cooling times and rates in different liquids

This is a summary of the curves shown in Figures 1, 2, and 3.

repeated cycles of steam generation, momentary attachment of steam to the metal surface and its removal.

In any case, hot water at temperatures in the neighborhood of $80^{\circ}$ to $100^{\circ} \mathrm{C}$. is not a good quenching medium under ordinary conditions. Where somewhat slower cooling is desired than can be secured in water at $20^{\circ} \mathrm{C}$., and the oils are too slow, possibilities may be found in hot brines and, more particularly, in the hot sodiumhydroxide solutions. The center cooling curves were generally smooth without abrupt changes in direction for water at $40^{\circ} \mathrm{C}$. and 5 per cent sodium hydroxide at $60^{\circ}$ to $80^{\circ} \mathrm{C}$. Also cooling times were obtained in the hot sodium-hydroxide solutions which were between water and oils at ordinary temperatures, as is shown in Table 2.

8 See footnote 4, p. 399.

$64335^{\circ}-29-5$ 
TABLE 2.-Comparisons of hot water or hot aqueous solutions with oils at atmospheric temperatures in cooling high-carbon steel cylinders from $875^{\circ} \mathrm{C}$.

AT CENTER

\begin{tabular}{|c|c|c|c|c|c|c|}
\hline \multirow{2}{*}{ Coolant } & \multicolumn{6}{|c|}{$\begin{array}{l}\text { Approximate time, in seconds, to cool from } 875^{\circ} \\
\text { C. to designated temperature } 1\end{array}$} \\
\hline & $800^{\circ} \mathrm{C}$. & $700^{\circ} \mathrm{C}$. & $600^{\circ} \mathrm{C}$. & $500^{\circ} \mathrm{C}$. & $400^{\circ} \mathrm{C}$. & $200^{\circ} \mathrm{C}$. \\
\hline $\begin{array}{l}\text { Water at } 20^{\circ} \mathrm{C} \\
5 \text { per cent } \mathrm{NaOH} \text { at } 60^{\circ} \mathrm{C} \\
\text { Water at } 40^{\circ} \mathrm{C}- \\
5 \text { per cent } \mathrm{NaCl} \text { at } 60^{\circ} \mathrm{C}\end{array}$ & $\begin{array}{l}1.4 \\
1.6 \\
1.6 \\
2.0\end{array}$ & $\begin{array}{l}2.0 \\
2.2 \\
2.3 \\
2.8\end{array}$ & $\begin{array}{l}2.6 \\
2.8 \\
3.0 \\
3.5\end{array}$ & $\begin{array}{l}3.2 \\
3.5 \\
3.9 \\
4.4\end{array}$ & $\begin{array}{l}4.1 \\
4.3 \\
4.8 \\
5.5\end{array}$ & $\begin{array}{r}8.6 \\
8.8 \\
9.4 \\
11.8\end{array}$ \\
\hline $\begin{array}{l}5 \text { per cent } \mathrm{NaOH} \text { at } 80^{\circ} \mathrm{C} \\
\mathrm{No} .1 \text { oil at } 20^{\circ} \mathrm{C} \text {. } \\
5 \text { per cent } \mathrm{NaCl} \text { at } 80^{\circ} \mathrm{C} \\
\mathrm{No} .2 \text { oil at } 20^{\circ} \mathrm{C}\end{array}$ & $\begin{array}{l}3.4 \\
2.9 \\
3.9 \\
3.6\end{array}$ & $\begin{array}{l}4.8 \\
4.9 \\
7.1 \\
6.2\end{array}$ & $\begin{array}{l}6.0 \\
7.5 \\
9.4 \\
8.8\end{array}$ & $\begin{array}{r}7.1 \\
11.1 \\
10.9 \\
12.4\end{array}$ & $\begin{array}{r}8.3 \\
15.6 \\
12.1 \\
16.5\end{array}$ & $\begin{array}{l}14.1 \\
28.8 \\
16.0 \\
29.7\end{array}$ \\
\hline \multicolumn{7}{|c|}{ AT SURFACE } \\
\hline $\begin{array}{l}\text { Water at } 20^{\circ} \mathrm{C} \\
5 \text { per cent } \mathrm{NaOH} \text { at } 60^{\circ} \mathrm{C}- \\
\text { Water at } 40^{\circ} \mathrm{C} \text { per cent } \mathrm{NaCl} \text { at } 60^{\circ} \mathrm{C}\end{array}$ & $\begin{array}{l}0.02 \\
.03 \\
.06 \\
.03\end{array}$ & $\begin{array}{l}0.07 \\
.08 \\
.14 \\
.11\end{array}$ & $\begin{array}{r}0.12 \\
.11 \\
.22 \\
.22\end{array}$ & $\begin{array}{r}0.21 \\
.15 \\
.34 \\
.38\end{array}$ & $\begin{array}{r}0.38 \\
.24 \\
.56 \\
.62\end{array}$ & $\begin{array}{l}1.2 \\
1.0 \\
2.0 \\
1.8\end{array}$ \\
\hline $\begin{array}{l}5 \text { per cent } \mathrm{NaOH} \text { at } 80^{\circ} \mathrm{C} \\
\text { No. } 1 \text { oil at } 20^{\circ} \mathrm{C}_{\mathrm{C}} \\
5 \text { per cent } \mathrm{NaCl} \text { at } 80^{\circ} \mathrm{C} \\
\text { No } 2 \text { oil at } 20^{\circ} \mathrm{C}\end{array}$ & $\begin{array}{l}.07 \\
.07 \\
.10 \\
.09\end{array}$ & $\begin{array}{l}.15 \\
.15 \\
.30 \\
.27\end{array}$ & $\begin{array}{l}.25 \\
.34 \\
.70 \\
.89\end{array}$ & $\begin{array}{l}.40 \\
.96 \\
1.48 \\
2.4\end{array}$ & $\begin{array}{l}.72 \\
2.5 \\
2.7 \\
5.5\end{array}$ & $\begin{array}{r}3.1 \\
14.7 \\
7.0 \\
19.3\end{array}$ \\
\hline
\end{tabular}

1 Heat effects of transformations disregarded.

In examining the data in Table 2 it should be kept in mind that the cooling curves obtained in aqueous solutions have a somewhat different form than those in the oils, and for this reason short cooling times at high temperatures are not necessarily concomitant with short cooling times to low temperatures. The cooling at low temperatures in oils is generally slower than that in aqueous solutions, as is shown in Figures 1,2, and 3, and Table 2, and the temperature of the coolant which may give the desired results will depend upon the steel under treatment, its size and shape, etc.

\section{HARDNESS AND STRUCTURES PRODUCED BY THE DIFFERENT COOLANTS}

The effects of temperature of the coolant on the hardness and structures produced in the one-half inch diameter $\times 2$-inch cylinders of 0.96 per cent carbon steel are shown, together with cooling times, in Figures 5 to 9 , inclusive. Figure 10 contains direct comparisons of the Rockwell hardnesses produced by quenching in the different liquids at different temperatures.

The fully hardened 0.96 per cent carbon steel, having a martensitic structure free from readily detectable areas of troostite, had a Rockwell "C" scale hardness of 63 to 65 . This hardness was not attained at surface or center when the steel was quenched in either of the two oils, but was obtained at the center with water up to $60^{\circ} \mathrm{C}$., 5 per cent sodium chloride up to $70^{\circ} \mathrm{C}$., and 5 per cent sodium hydroxide up to $80^{\circ}$ C. (Fig. 10.) With increase above the designated temperatures the hardness dropped appreciably and rapidly. 


\section{$5 \% \mathrm{NaOH}$}

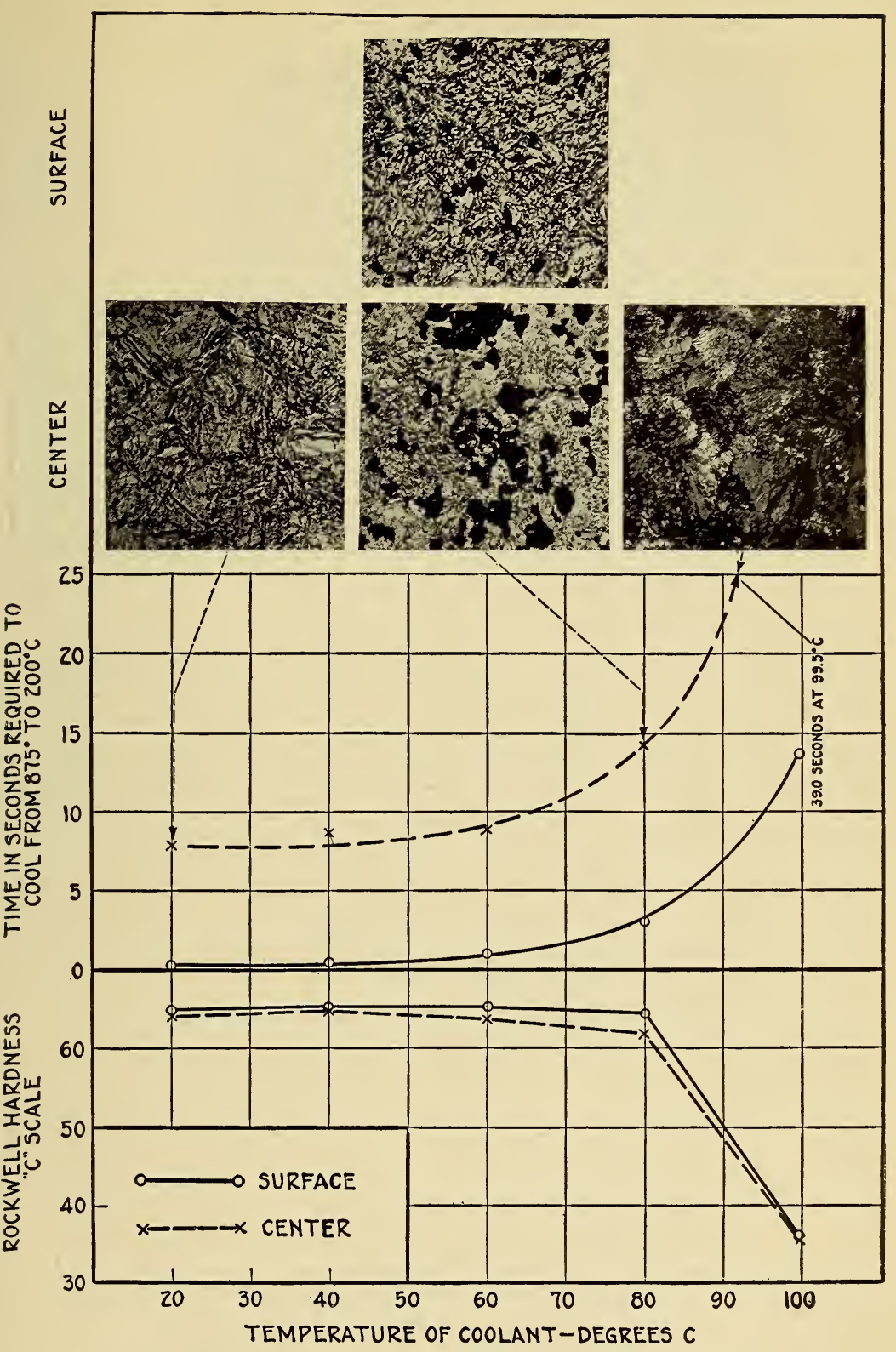

Figure 5.-Hardness, cooling times, and structure at the center and surface of 0.96 per cent carbon steel cylinders quenched from $875^{\circ} \mathrm{C}$. into 5 per cent sodium hydroxide at different temperatures

Coolant motion 3 feet per second; cylinders $1 / 2$ inch diameter by 2 inches long. Microstructures $\times 225$; samples etched in 2 per cent $\mathrm{HNO}_{3}$ in alcohol. Where surface structures resembled those at the center only the latter are given. 
$5 \% \mathrm{NaCl}$

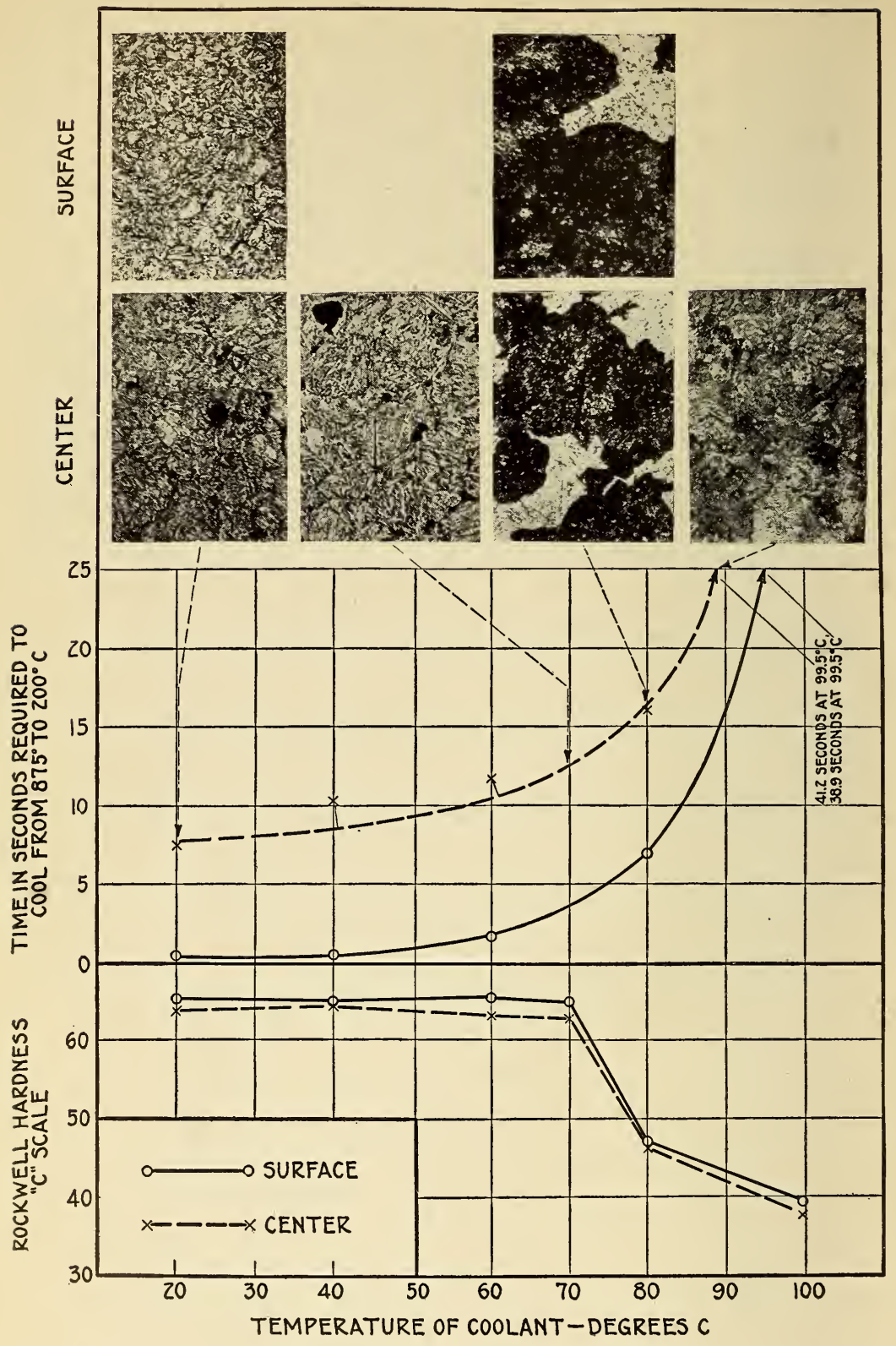

FIgURE 6.-Hardness, cooling times, and structure at the center and surface of 0.96 per cent carbon steel cylinders quenched from $875^{\circ} \mathrm{C}$. into 5 per cent sodium chloride at different temperatures

Coolant motion 3 feet per second; cylinders $1 / 2$ inch diameter by 2 inches long. Microstructures $\times 225$; samples etshed in 2 per cent $\mathrm{HNO}_{3}$ in alcohol. Where surface structures resembled those at the center only the latter are given. 
WATER

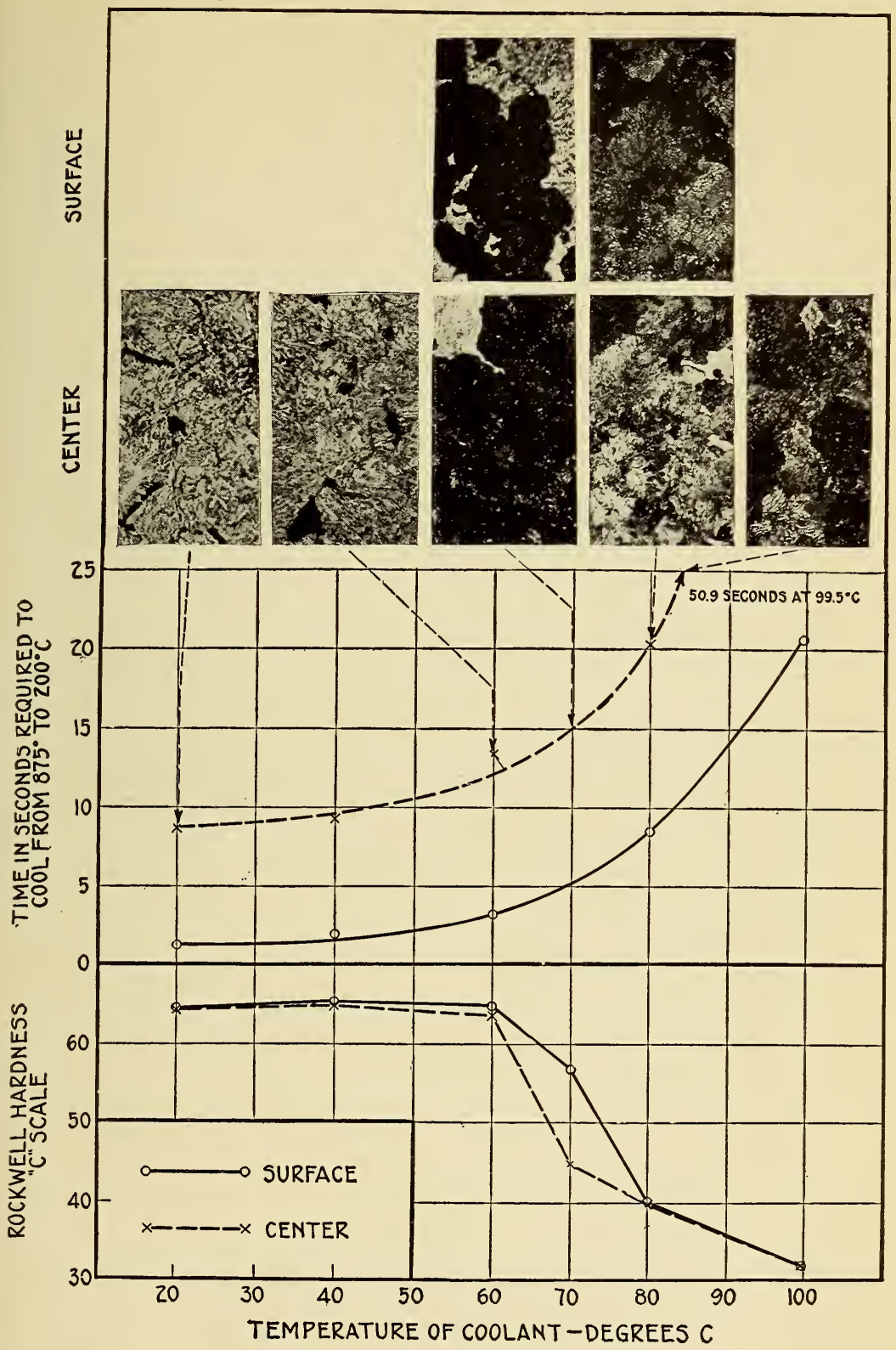

FIGURE 7.-Hardness, cooling times, and structure at the center and surface of 0.96 per cent carbon steel cylinders quenched from $875^{\circ} \mathrm{C}$. into water at different temperatures

Coolant motion 3 feet per second; cylinders $1 / 2$ inch diameter by 2 inches long. Microstructures $\times 225$; samples etched in 2 per cent $\mathrm{HNO}_{3}$ in alcohol. Where surface structures resembled those at the center only the latter are given. 
NO.2 OIL

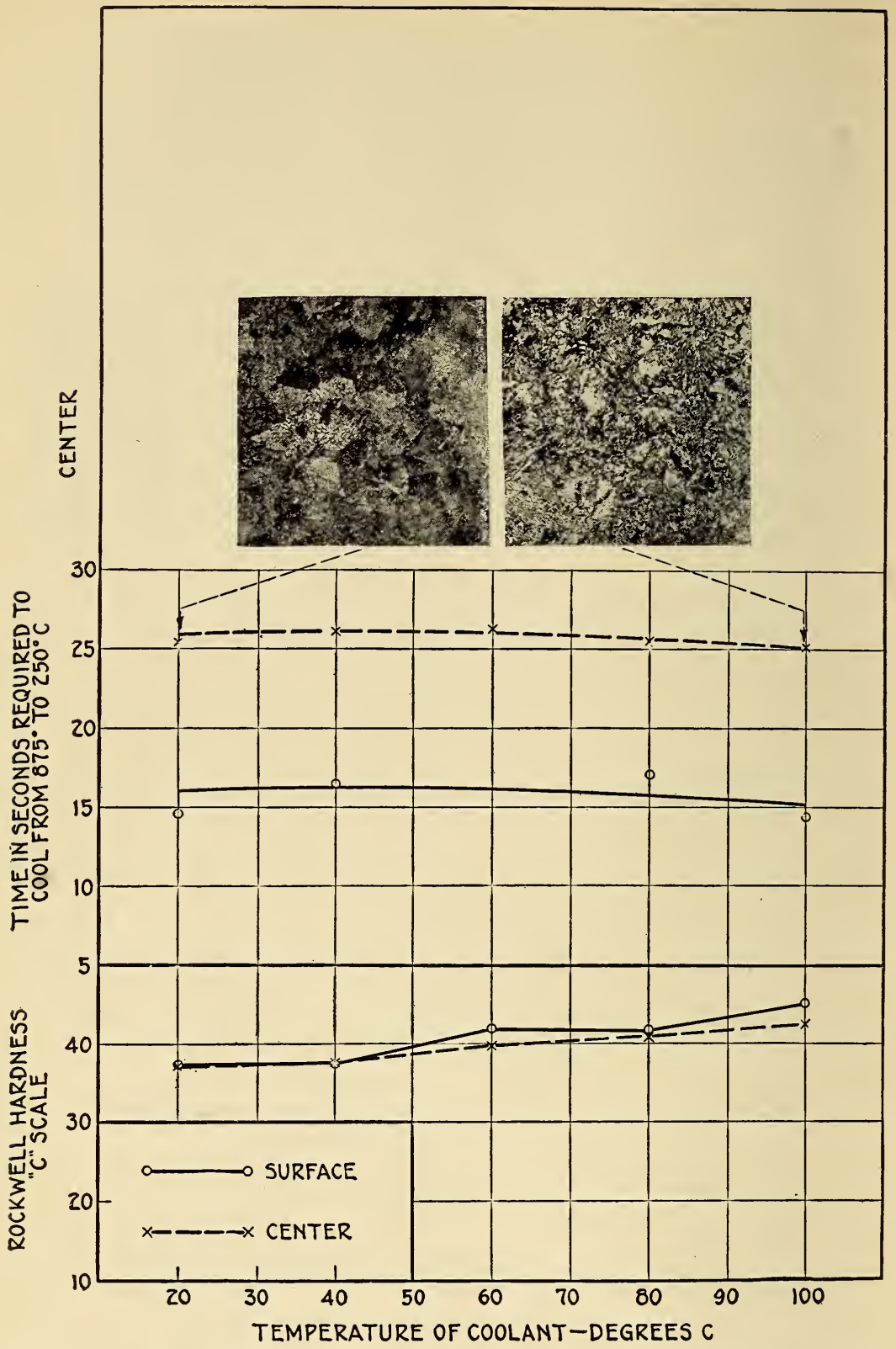

Figdre 8.-Hardness, cooling times, and structure at the center and surface of 0.96 per cent carbon steel cylinders quenched from $875^{\circ} \mathrm{C}$. into No. 2 oil at different temperatures

Coolant motion 3 feet per second; cylinders 1/2 inch diameter by 2 inches long. Microstructures $\times 225$; samples etched in 2 per cent $\mathrm{HNO}_{3}$ in alcohol. Where surface structures resembled those at the center only the latter are given. 
While water at $60^{\circ} \mathrm{C}$., 5 per cent sodium ehloride at $70^{\circ} \mathrm{C}$, , and 5 per cent sodium hydroxide at $80^{\circ} \mathrm{C}$. produced a Rockwell hardness equivalent to that obtained from the same coolants at atmospheric temperatures, there were appreciable differences in the structures of the quenched steels. In gencral, as the temperature of the coolant was increased, the structure changed from martensite (plus austenite) to martensite with increasing amounts of primary troostite, and finally to troosto-sorbite and sorbite with some evidence of lamellar pearlite.

Emphasis should be placed upon the fact that the hardness of the martensitic samples practically free from troostite was substantially

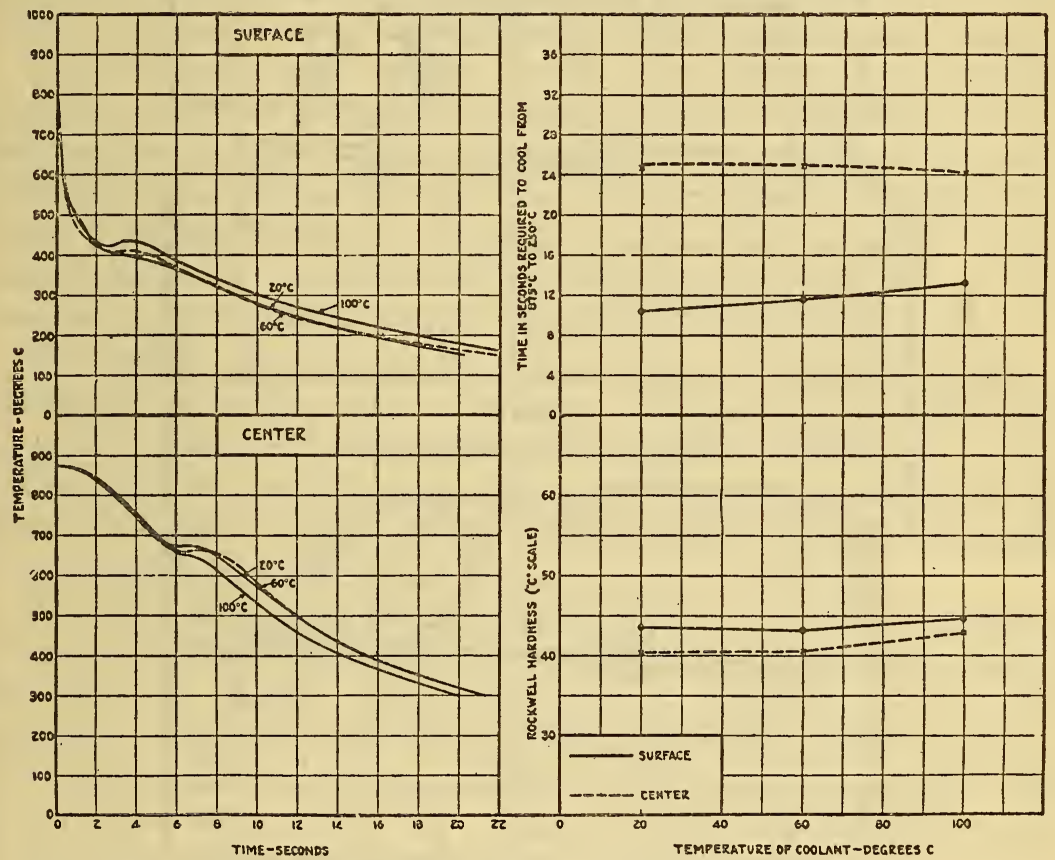

FiguRE 9.-Cooling curves, cooling times and hardness at center and surface of 0.96 per cent carbon steel cylinders quenched in No. 1 oil at different temperatures

Coolant motion 3 feet per second; cylinders $1 / 2$ inch diameter by 2 inches long.

the same as that of the samples containing appreciable proportions of troostite. Hardness tests are frequently used in inspection to insure satisfactory heat treatment but may be inadequate when the properties desired are represented by martensite free from troostite.

Complete martensitization to the center of the one-half inch diameter cylinders was obtained only in the 5 per cent sodium-hydroxide solution at $20^{\circ} \mathrm{C}$., whereas in previously reported tests ${ }^{9}$ of a similar steel this was produced in water at $20^{\circ} \mathrm{C}$. This difference may be ascribed to differences in the critical cooling rates of the two lots of steel;

- See footnote 1, p. 399. 
that is, different cooling rates are required by different heats of steel of similar carbon content for the production of martensite free from troostite. ${ }^{10}$

As has been indicated already the effects of temperature of the coolant on the cooling of the steels quenched in oil were small but opposite to the effects observed in water and the aqueous solutions. The cooling was slightly faster in the No. 2 oil at $100^{\circ} \mathrm{C}$. than at

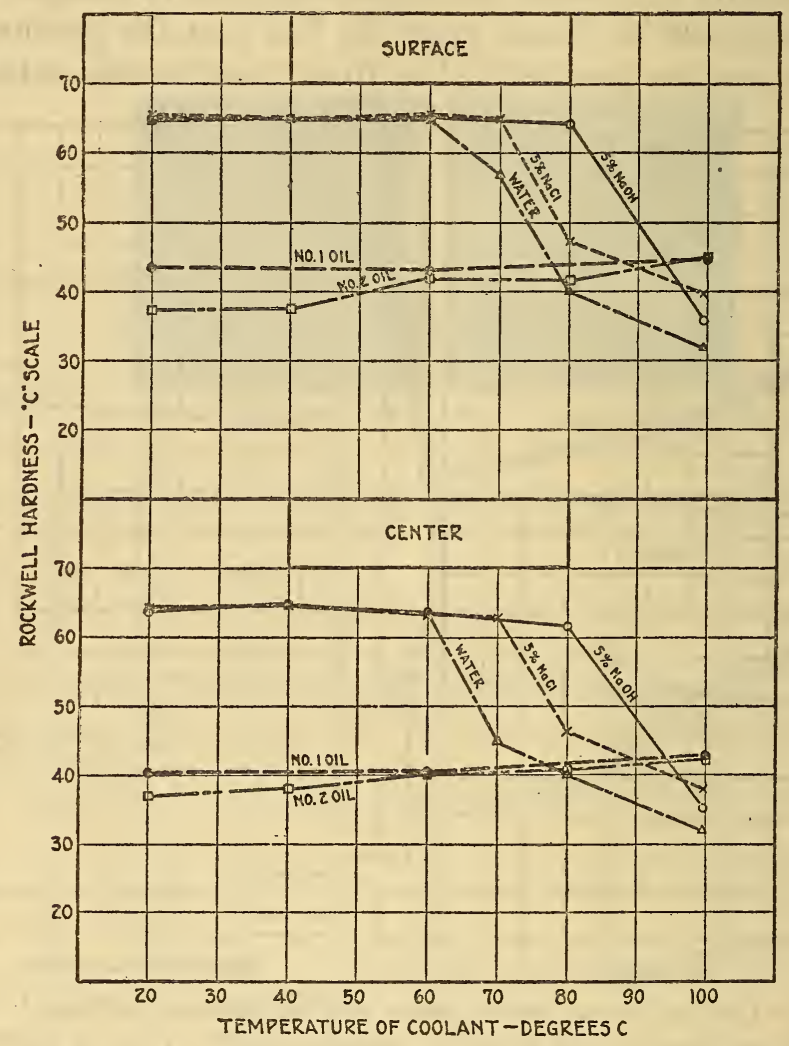

Figure 10.-Surface and center hardnesses of the 0.96 per cent carbon steel cylinders quenched from $875^{\circ} \mathrm{C}$. into different liquids at different temperatures

Coolant motion 3 feet per second; cylinders $1 / 2$ inch diameter by 2 inches long.

$20^{\circ} \mathrm{C}$. (figs. 1 and 2), and this was confirmed by the hardness tests reported in Figure 8. A similar result was shown in the No. 1 oil (fig. 9), but the changes were somewhat smaller. However, not all oils show increased speeds of cooling with increase in temperature ${ }^{11}$ as in the two cases cited.

10 General recognition of this is associated with the pioneer work on "abnormal" steels by McQuaid and Ehn, summarized along with more recent work in a paper by S. Epstein and H. S. Rawdon; Steel for Casehardening-Normal and Abnormal Steel, B. S. Jour. Research, 1, p. 423; 1928.

11 J. A. Mathews and H. J. Stagg, Factors in Hardening Tool Steel, Trans., Am. Soc. Mech. Engrs., 36, p. 845; 1914. 


\section{LIQUIDS WITH GRADED COOLING SPEEDS}

Present-day hardening practice is based quite largely upon the use of oils, water, and the more rapid aqueous solutions, such as sodiumchloride brines, sodium-hydroxide solutions, and water sprays at ordinary temperatures. There is a large gap between the cooling rates obtained in the customary quenching oils and in water, and this is now usually taken care of by tempering subsequent to hardening or by interrupted quenching. Such procedure is entirely satisfactory for many practical purposes, but simplification and economy and possibly also technical advantages would result if coolants were available to provide a more closely graded set of cooling characteristics.

The practical solution of this problem is not solely one of obtaining certain prescribed cooling rates, since general availability and cost, permanence, safety from the standpoint of the operators, properties affecting adherence to the quenched metals which, in turn, affect the losses from the bath and cleaning costs, as well as other factors, should be given consideration. Nevertheless, one of the principal requirements is meeting certain prescribed cooling rates.

The liquids discussed in previous sections of this report offer a graded set of cooling rates from those of water and the more rapid aqueous solutions at atmospheric temperatures to those of the customary oils and in this respect they are of interest, although only some would be classed as good or useful coolants from the viewpoint of practical heat treatment.

The most promising group selected from the liquids considered are given in Table 3 in order of decrease in the speeds, or increase in the times, of cooling. The order given is correct in so far as the hardness, structures, and center cooling times from $875^{\circ}$ to $200^{\circ} \mathrm{C}$. are concerned, but not necessarily so for the cooling through other temperature ranges, since the cooling curves of the different liquids do not all have the same form.

A list based on somewhat closer gradations can be prepared from the data in Figures 1 to 10, inclusive, and substitutions can be made in a number of cases, but in Table 3 coolants showing the strongest tendencies toward irregular results have been omitted; only those were chosen in which smooth center cooling curves were obtained with fairly uniform slopes from $850^{\circ}$ to $200^{\circ}$ or $300^{\circ} \mathrm{C}$.

The corrosive nature of the hot sodium-hydroxide solutions and the hot sodium-chloride brines is at the same time an advantage and a disadvantage. These solutions would not be easy to handle industrially from the standpoint of either equipment or operators, but the quenched steels are relatively free from heavy scale, and with bath temperatures of $60^{\circ}$ to $80^{\circ} \mathrm{C}$. or less will often come out bright. This denotes active scale removal during the quench, an effect which tends to promote uniformity in the results obtained. 
TABLE 3.-List of liquids given in order of decrease in cooling speeds MORE RAPID THAN WATER

\begin{tabular}{|c|c|c|}
\hline \multirow[t]{2}{*}{ Liquid and temperature } & \multicolumn{2}{|c|}{$\begin{array}{l}\text { Cooling time from } \\
875^{\circ} \text { to } 200^{\circ} \mathrm{C} .1 \text { in } \\
\text { seconds for- }\end{array}$} \\
\hline & Surface & Center \\
\hline 5 per cent $\mathrm{NaOH}$ at $20^{\circ} \mathrm{C}$.- & 0.31 & \\
\hline 5 per cent $\mathrm{NaCl}$ at $20^{\circ} \mathrm{C}$ & .48 & 7.4 \\
\hline r at $20^{\circ} \mathrm{C}$ & 1.2 & 8.6 \\
\hline
\end{tabular}

RATES BETWEEN WATER AND OILS

\begin{tabular}{|c|c|c|}
\hline 5 per cent $\mathrm{NaOH}$ at $60^{\circ} \mathrm{C}$ & 1.03 & \\
\hline 5 per cent $\mathrm{NaCl}$ at $60^{\circ} \mathrm{C}$. & 1.8 & 11.8 \\
\hline Water at $60^{\circ} \mathrm{C}_{-}$ & 3.2 & 13.4 \\
\hline 5 per cent $\mathrm{NaOH}$ a & 3.1 & 14.2 \\
\hline
\end{tabular}

RATES CLOSE TO OR OF OILS

5 per cent $\mathrm{NaOH}$ at $85^{\circ} \mathrm{C}$.

5 per cent $\mathrm{NaOH}$ at $90^{\circ} \mathrm{C}$

No. 1 oil at $20^{\circ} \mathrm{C}$.

No. 2 oil at $20^{\circ} \mathrm{C}$

${ }^{1}$ For 0.96 per cent $\mathrm{C}$ steel cylinders one-half inch diameter by 2 inches long; liquid moving at 3 feet per second.

Bracketed values estimated by interpolation.

Observations during the experiments clearly indicated that as the temperature of the sodium chloride and hydroxide solutions approached the boiling point of water there was a decided decrease in the uniformity of the conditions at the contact surfaces of the steel and the coolant. However, it should be kept in mind that all the experiments were made with low coolant velocities and that if better circulation were provided more uniform conditions could be expected. Liquids unsatisfactory at low rates of motion might become satisfactory at higher rates of motion.

\section{TENSILE PROPERTIES PRODUCED BY THE HOT AQUEOUS SOLUTIONS}

Two sets of tensile test bars were quenched in some of the hot aqueous solutions to give additional comparisons with water and the No. 2 oil at atmospheric temperatures. The first set was prepared from an oil-hardening nickel-chromium steel, while the second comprised specimens of 0.45 per cent carbon steel. The results of the tensile tests are summarized in Tables 4 and 5 .

In the case of the nickel-chromium steel (Table 4) somewhat better uniformity was obtained in the two oil-quenched samples than in those which were quenched in water at $70^{\circ} \mathrm{C}$., but the best combination of strength and ductility was obtained in samples quenched 
in 5 per cent sodium hydroxide at $80^{\circ} \mathrm{C}$. The results obtained with 5 per cent sodium chloride at $80^{\circ} \mathrm{C}$. were not as good as those with the sodium hydroxide at $80^{\circ} \mathrm{C}$., but as the temperature of the sodium hydroxide was increased to $85^{\circ}$ and $90^{\circ} \mathrm{C}$. there was a decrease in both the strength and ductility.

TABLE 4.-Tensile properiies of a $\mathrm{Cr}-\mathrm{Ni}$ steel quenched from $840^{\circ} \mathrm{C} .\left(1,550^{\circ} \mathrm{F}\right.$.) into different liquids moving at 3 feet per second 1

(C, 0.23; Cr, 1.06; Ni, 1.64; P, 0.021; S 0.020)

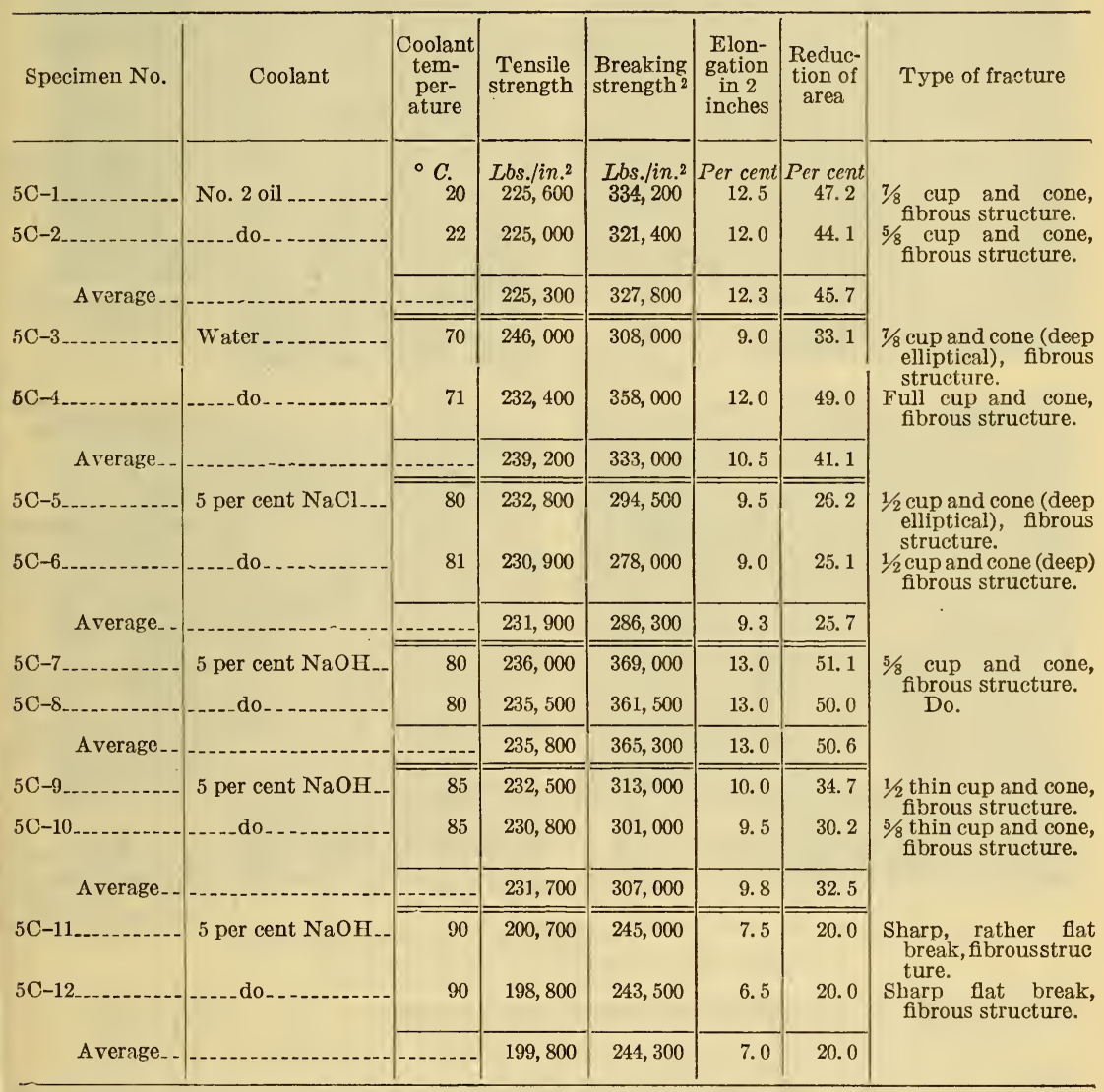

1 Specimens were held 30 minutes at temperature before quenching.

2 The load at fracture divided by the area of the fractured section.

The specimens of 0.45 per cent carbon steel cracked when quenched in the 5 per cent sodium hydroxide at $80^{\circ} \mathrm{C}$. (Table 5). Poor mechanical properties were obtained in the same liquid at $85^{\circ} \mathrm{C}$., but when the temperature was raised to $90^{\circ} \mathrm{C}$. an excellent combination of strength and ductility was obtained. Good strength, elongation, and reduction of area were also obtained in 5 per cent sodium chloride at $80^{\circ} \mathrm{C}$., but erratic results were obtained in water at $70^{\circ} \mathrm{C}$. Hankins 
and Ford ${ }^{12}$ tried unsuccessfully to quench 18-inch tensile specimens, 3 inches wide and three-eighths inch thick, of a 0.60 per cent carbon steel from $800^{\circ} \mathrm{C}$. into water at $50^{\circ} \mathrm{C}$. without cracking after being successful with 3 and 6 inch plates of the same width and thickness.

TABLE 5.-Tensile properties of a 0.44 per cent carbon steel quenched from $815^{\circ} \mathrm{C}$. $\left(1,500^{\circ} F.\right)$ into different liquids moving at 3 feet per second 1

(C, $0.44 ; \mathrm{Mn}, 0.81 ; \mathrm{P}, 0.025 ; \mathrm{S}, 0.022)$

\begin{tabular}{|c|c|c|c|c|c|c|c|}
\hline Specimen No. & Coolant & $\begin{array}{c}\text { Coolant } \\
\text { tem- } \\
\text { per- } \\
\text { ature }\end{array}$ & $\begin{array}{l}\text { Tensile } \\
\text { strength }\end{array}$ & $\begin{array}{l}\text { Breaking } \\
\text { strength }^{2}\end{array}$ & $\begin{array}{l}\text { Elon- } \\
\text { gation } \\
\text { in } 2 \\
\text { inches }\end{array}$ & $\begin{array}{l}\text { Reduc- } \\
\text { tion of } \\
\text { area }\end{array}$ & Type of fracture \\
\hline $7 \mathrm{~A}-1$ & \multirow{2}{*}{ No. 2 oil } & ${ }^{\circ} C_{18}$ & $\begin{array}{r}\text { Thbs./in. }{ }^{2} \\
128,500\end{array}$ & $\begin{array}{r}\text { Lbs./in. }{ }^{2} \\
135,200\end{array}$ & $\begin{array}{c}\text { Per cent } \\
1.5\end{array}$ & $\begin{array}{c}\text { Per cent } \\
4.7\end{array}$ & \multirow{3}{*}{$\begin{array}{l}\text { Fine crystallinestruc- } \\
\text { ture, sharp break. } \\
\text { Do. }\end{array}$} \\
\hline $7 \mathrm{~A}-2$ & & 21 & 148,500 & 158,000 & 1.0 & 5.9 & \\
\hline A verage _. & &.- & 138,500 & 146,600 & 1.3 & 5.3 & \\
\hline $\begin{array}{l}7 \mathrm{~A}-3 \\
\mathrm{~A}-4\end{array}$ & Water & $\begin{array}{l}70 \\
70\end{array}$ & $\begin{array}{l}106,500 \\
127,200\end{array}$ & $\begin{array}{l}111,500 \\
198,800\end{array}$ & $\begin{array}{r}3.0 \\
14.0\end{array}$ & $\begin{array}{r}4.5 \\
54.8\end{array}$ & \multirow{5}{*}{$\begin{array}{l}\text { Do. } \\
\text { 7/8 deep cup and cone, } \\
\text { fibrous structure. } \\
\text { 5/8 deep cup and cone, } \\
\text { fibrous structure. } \\
\text { Do. }\end{array}$} \\
\hline A verage & & - & 116,900 & 155,200 & 8.5 & 29.7 & \\
\hline $7 \mathrm{~A}-5$ & \multirow{3}{*}{5 per cent $\mathrm{NaCl}$} & 79 & 119,200 & 189,300 & 17.0 & 47.2 & \\
\hline $7 \mathrm{~A}-6$ & & 81 & 118,500 & 201,000 & 17.5 & 51.7 & \\
\hline A verage. - & & $\cdots$ & 118,900 & 195,200 & 17.3 & 49.5 & \\
\hline$A-$ & 55 per cen & $\begin{array}{l}80 \\
80\end{array}$ & \multicolumn{4}{|c|}{\}$_{\text {ing }}^{\text {Both specimens cracked in quench- }}$} & \multirow{3}{*}{$\begin{array}{l}\text { Very fine crystalline } \\
\text { structure, sharp } \\
\text { break. } \\
\text { Very fine crystalline } \\
\text { structure, rather } \\
\text { sharp break. } \\
\text { Very fine crystalline } \\
\text { structure, sharp } \\
\text { break. } \\
\text { Very fine crystalline } \\
\text { structure, rather } \\
\text { sharp break. }\end{array}$} \\
\hline $7 \mathrm{~A}-9$ & _..._do... & 85 & 77,500 & 80,800 & 1.0 & & \\
\hline $7 \mathrm{~A}-10$ & ...do_. & 85 & 95,700 & 98,700 & 1.0 & 2.8 & \\
\hline Average. - & & $-\ldots$ & 86,600 & 89,800 & 1.0 & 3.4 & \\
\hline $7 \mathrm{~A}-11$ & 5 per cent $\mathrm{NaOH}$. & 90 & 114,700 & 200,000 & 20.5 & 55.3 & $3 / 4$ cup and cone, \\
\hline $7 \mathrm{~A}-12$ & ....do_. & 90 & 114,700 & 195,600 & 20.5 & 54.2 & $\begin{array}{l}5 / 8 \text { cup and cone, } \\
\text { fibrous structure. }\end{array}$ \\
\hline A verage. . & & & 114,700 & 197,800 & 20.5 & 54.8 & \\
\hline
\end{tabular}

1 Specimens were held 30 minutes at temperature before quenching.

2 The load at fracture divided by the area of the fractured section.

The structures of some of the tensile-test specimens are shown in Figures 11 and 12. The No. 2 oil at $20^{\circ} \mathrm{C}$. and the 5 per cent sodium hydroxide at $90^{\circ} \mathrm{C}$. produced a troosto-sorbitic structure in the 0.45 per cent carbon steel, while the 5 per cent sodium chloride at $80^{\circ} \mathrm{C}$. and the 5 per cent sodium hydroxide at $85^{\circ} \mathrm{C}$. produced a martensitic structure containing appreciable proportions of troostite. The differences in ductility and tensile strength in samples $7 \mathrm{~A}-9$ and $7 \mathrm{~A}-5$ (fig. 11) were probably due in part to differences in the degree of

12 G. A. Hankins and G. W. Ford, The Mechanical and Metallurgical Properties of Spring Steels as Revealed by Laboratory Tests. A paper to be presented before the 1929 spring meeting of the British Iron and Steel Institute. 

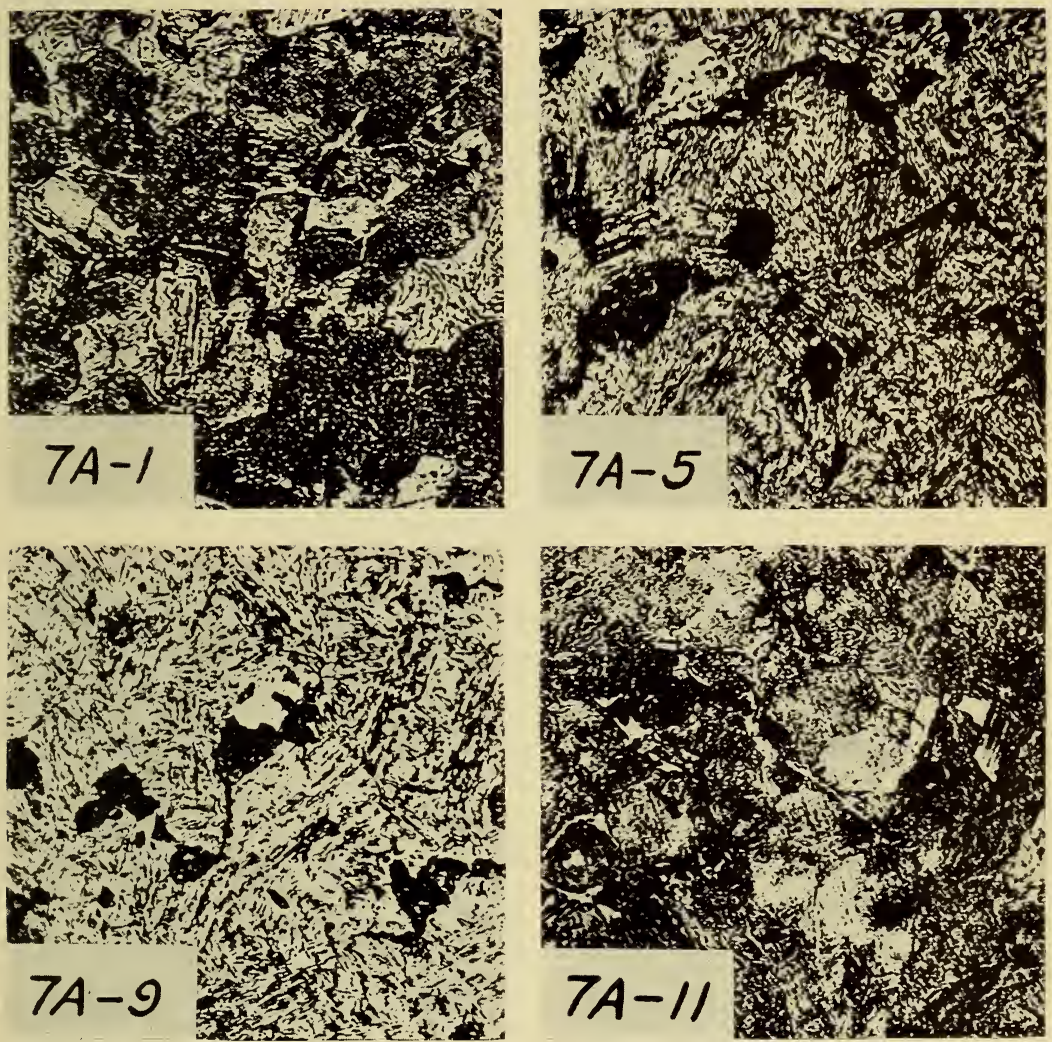

Figure 11.-Microstructures and physical properties of some of the tensile specimens tested, summarized in Table 5

Microstructures which were taken at center of the tensile specimens $\times 400$; samples etched in 2 per cent $\mathrm{HNO}_{3}$ in alcohol.

Specimen $7 \mathrm{~A}-1$, quenched in No. 2 oil at $20^{\circ} \mathrm{C}$. (3 feet per second); tensile strength, 128,500 lbs./in.2; elongation in 2 inches, 1.5 per cent; reduction of area, 4.7 per cent; Rockwell hardness, " $\mathrm{C}$ " scale, 31 .

Specimen $7 \mathrm{~A}-5$, quenched in 5 per cent $\mathrm{NaCl}$ at $80^{\circ} \mathrm{C}$. (3 feet per second); tensile strength $119,2 \mathrm{~N}$ lbs./in. ${ }^{2}$; elongation in 2 inches, 17.0 per cent; reduction of area, 47.2 per cent; Rockwell hardness, " $\mathrm{C}$ " scale, 49.

Specimen $7 \mathrm{~A}-9$, quenched in 5 per cent $\mathrm{NaOH}$ at $85^{\circ} \mathrm{C}$. ( 3 feet per second); tensile strength, 77,500 lbs./in. 2; elongation in 2 inches, 1.0 per cent, reduction of area, 4.0 per cent; Rockwell hardness, "C" scale, 53 .

Specimen $7 \mathrm{~A}-11$, quenched in 5 per cent $\mathrm{NaOH}$ at $90^{\circ} \mathrm{C}$. (3 feet per second); tensile strength 114,700 lbs./in. ${ }^{2}$; elongation in 2 inches, 20.5 per cent; reduction of area, 65.3 per cent; Rockwell hardness, "C" scale, 2 . 
B. S. Journal of Research, RP103
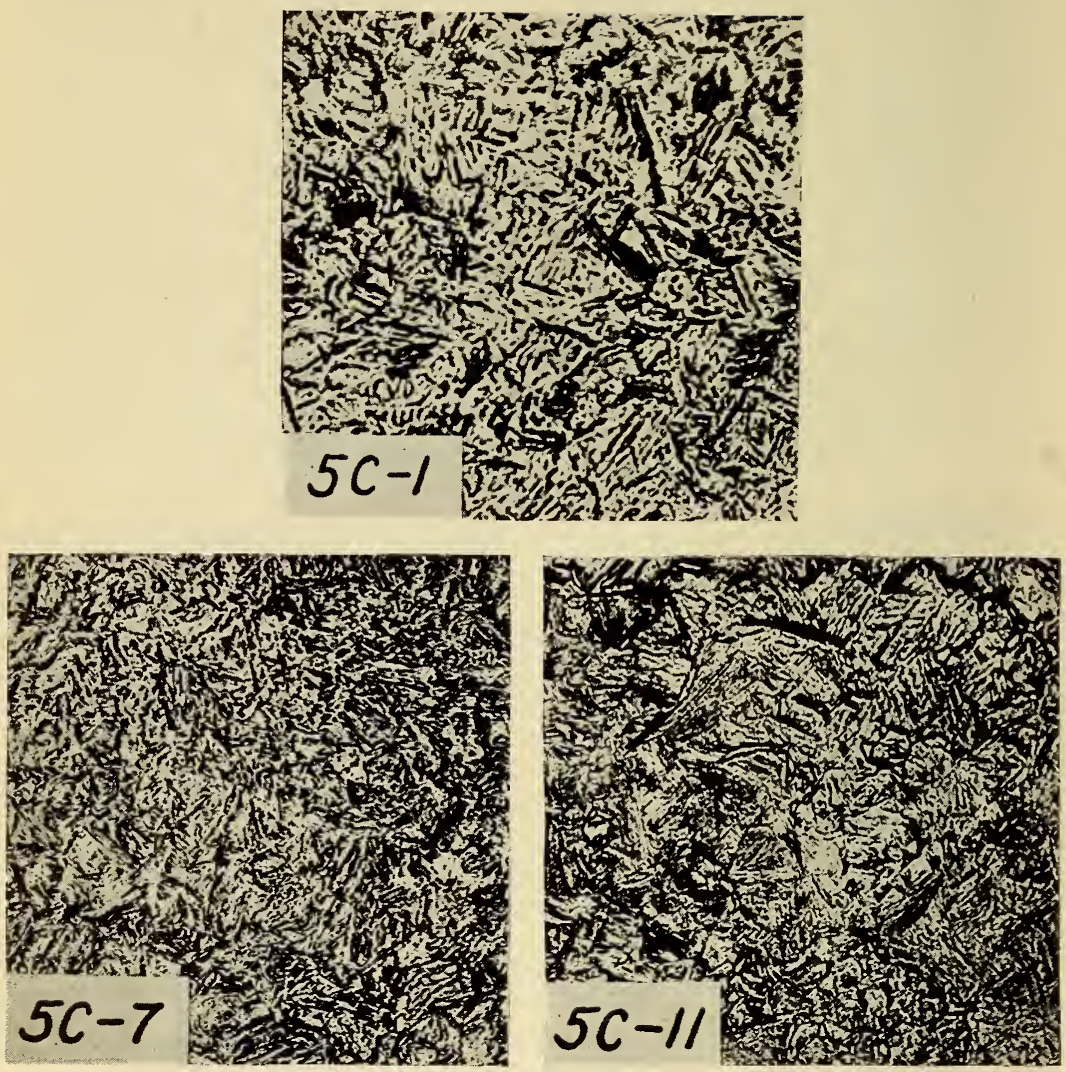

Figure 12.-Microstructuers and physical properties of some of the tensile specimens tested, summarized in Table 4

Microstructures which were taken at center of the tensile specimens $\times 400$; samples etched in 2 per cent $\mathrm{HNO}_{3}$ in alcohol.

Specimen $5 \mathrm{C}-1$, quenched in No. 2 oil at $20^{\circ} \mathrm{C}$. (3 feet per second); tensile strength, 225,600 lbs./in.2; elongation in 2 inches, 12.5 per cent; reduction of area, 47.2 per cent; Rockwell hardness, "C" scale, 46. Specimen $5 \mathrm{C}-7$, quenched in 5 per cent $\mathrm{NaOH}$ at $80^{\circ} \mathrm{C}$. (3 feet per second); tensilestrength, 236,000 lbs./in.2; elongation in 2 inches, 13.0 per cent; reduction of area 51.1 per cent; Rockwell hardness, "C": scale, 48. 1

Specimen $5 \mathrm{C}-11$, quenched in 5 per cent $\mathrm{NaOH}$ at $90^{\circ} \mathrm{C}$. (3 feet per second); tensile strength, $200,700 \mathrm{lbs}$./in. ${ }^{2}$; elongation in 2 inches, 7.5 per cent; reduction of area, 20.0 per cent; Rockwell hardness, "C" scale, 46. 
tempering of the martensite, to differences in the proportions of troostite present and to differences in the residual stresses left by the volume changes in hardening.

The three nickel-chromium steel samples shown in Figure 12 showed structures consisting of partially tempered martensite; in the sample quenched in 5 per cent sodium hydroxide at $90^{\circ} \mathrm{C}$. dark needles were found suggesting the presence of troostite. These samples showed low tensile strength and ductility in comparison with the samples quenched in oil at $20^{\circ} \mathrm{C}$. or 5 per cent sodium hydroxide at $80^{\circ} \mathrm{C}$.

\section{DIMENSIONAL CHANGES IN THE HOT AQUEOUS SOLUTIONS}

Gages of the form and dimensions shown in Figure 13 were quenched in each of the two oils and in some of the hot aqueous solutions and
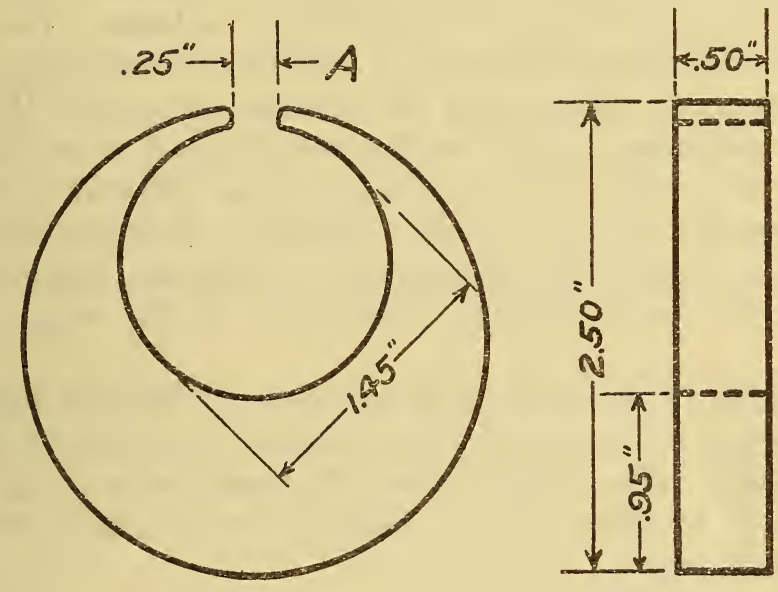

FigURE 13.-Form and dimensions of the gage used in the repeated quenching experiments

the resulting changes in diameter and in the width of the slot $A$ are summarized in Table 6.

The gages used were similar to those employed in the inspection of class 5 tool steels by the United States Navy Department, ${ }^{13}$ except that they were exactly half size in all dimensions. Johanssen gage blocks were used in measuring the width of the slot $A$ while the diameters were measured at points one-fourth to one-half inch from each side of the slot $A$. The gages were all brought to a constant temperature of $20^{\circ} \mathrm{C}$. before measurements were made.

For the first quench the gages were placed in a furnace at $815^{\circ} \mathrm{C}$., held 45 minutes and immersed in the chosen liquid. After the desired measurements had been rnade the gages were tempered for one hour at $230^{\circ} \mathrm{C}$. and again measured. Subsequently, the gages

${ }^{13} 0.80$ to 1.05 per cent C, 1.25 to 2.00 per cent Mn, Navy Department specifications for tool steel, No. 47S5e; July $1,1921$. 
were repeatedly quenched into the solutions first used, but in these cases they were held in the furnace only 15 minutes before quenching.

The steel originally selected for the tests was an "oil-hardening" steel containing about 0.9 per cent carbon, 1.2 per cent manganese, and about 0.5 per cent each of chromium and tungsten, but due to an error which was not discovered until after the experiments had been completed the gages were made from a steel containing 0.45 per cent carbon and 1 per cent chromium. However, this latter steel served the purpose of the experiments, since the coolants of greatest interest were those having cooling rates between the oils and ordinary tap water at atmospheric temperatures and an "oil-hardening" steel was not essential.

The object of the tests described was to detect in a practical and empirical manner conditions which might be characterized as dangerous in the application of the different coolants. The form of the specimen illustrated in Figure 13, with its thin and heavy sections, precludes uniform cooling and the stresses set up by the volume changes in hardening can not readily be calculated on account of the complexity of the conditions encountered in different parts of the gage but should certainly be high. Therefore, this specimen offers a means of detecting strong tendencies of the different coolants to promote distortion and cracking, irrespective of the causes of these effects.

The changes in diameter may be taken to indicate roughly the volume changes in hardening, while those in the width of the slot $A$ (fig. 13) should reflect qualitatively the magnitude of the internal stresses set up by these volume changes, since the ends forming the slot are free to move.

As is shown in Table 6, the changes in the width of the slot $A$ (fig. 13) were larger, per unit of measured length, than those in the diameter of the gages, but the two sets of changes showed simultaneous increases or decreases when comparing the different coolants. With one exception the changes were larger in the hot aqueous solutions than in the oils (Table 6). This one exception was the sodium hydroxide at $80^{\circ} \mathrm{C}$., in which the dimensional changes were about equal to those in the No. 2 oil and smaller than the changes in any of the other liquids except the No. 1 oil. The Rockwell hardness produced in metal adjacent to the slot was somewhat higher when the gages were quenched in the sodium hydroxide at $80^{\circ} \mathrm{C}$. (55, "C" scale) than when quenched in either of the oils (51 or 52 for both oils).

In all cases the changes produced by tempering for one hour at $230^{\circ} \mathrm{C}$. were small, and this may be taken to indicate that the widening of the slot in quenching effectively relieved a large part of the internal stresses produced by the volume changes in hardening. 


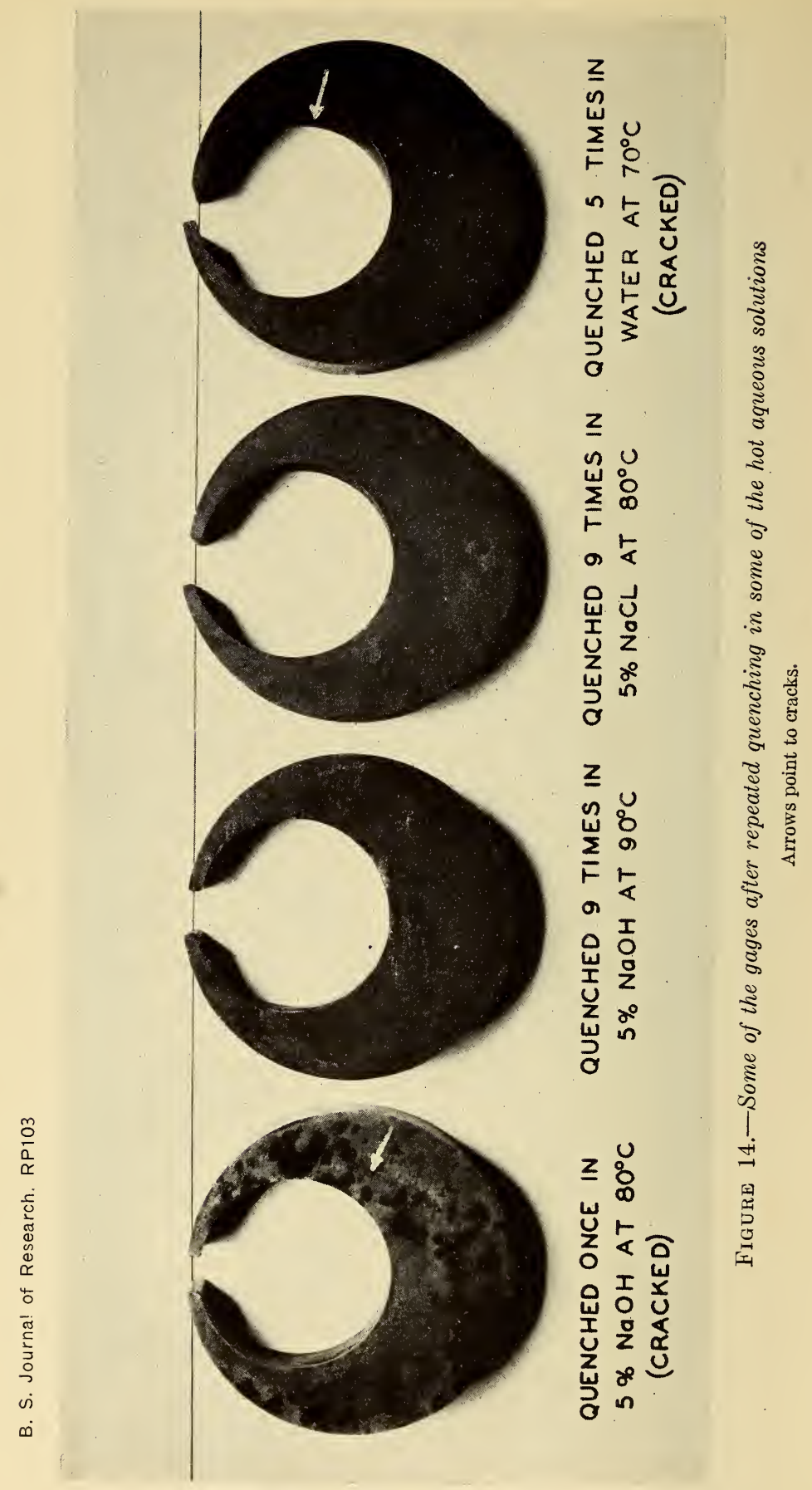


The results obtained in these experiments justify the view that some of the hot aqueous solutions can be useful in bridging the gap between the cooling rates obtained with water and oils at ordinary temperatures, but some of their characteristics must be recognized as sources of danger or disadvantage. The maintenance of rapid cooling at low temperatures may be undesirable in the hardening of some steels, but this also applies to drastic coolants, such as the cold brines and cold sodium-hydroxide solutions, now used industrially. Difficulties from this source can be minimized in some cases, at least, by removing the steel before it reaches coolant temperatures (interrupted quenching) and under suitably controlled conditions any benefits derived need not be at the expense of high hardness. Another source of danger in the hot aqueous solutions is lack of uniformity, promoted by the formation of relatively large amounts of steam, but this becomes more marked as the bath temperature approaches the boiling point of water and can probably be counteracted through adequate circulation and adjustment of coolant composition and temperature.

Such sources of danger are well recognized, but the hot aqueous solutions studied are not necessarily "poisonous" to steels as is illustrated by the results of the repeated quenching summarized in Table 6 .

Under the adverse conditions imposed by repeated introduction of the hardened steels into a furnace at high temperatures, without intermediate annealing, two of the gages cracked in the first and third quenchings in the 5 per cent sodium hydroxide at $80^{\circ} \mathrm{C}$., but five treatments were required for cracking in water at $70^{\circ} \mathrm{C}$., and the gages did not crack when quenched nine times in either 5 per cent sodium chloride at $80^{\circ} \mathrm{C}$. or 5 per cent sodium hydroxide at $90^{\circ} \mathrm{C}$.

The appearance of some of the repeatedly quenched gages is shown in Figure 14, and it will be observed that considerable distortion has taken place in the ends forming the slot in those gages which were quenched nine times without cracking. The cracks in the gages quenched in 5 per cent sodium hydroxide at $80^{\circ} \mathrm{C}$. were in the heavy section (see arrows, fig. 14), whereas those in the gages quenched in water at $70^{\circ} \mathrm{C}$. were circumferential at the hole in the specimen (see arrows, fig. 14).

Not enough tests have been made to determine the best of the liquids tested for different purposes nor the order of uniformity which may be expected under conditions of practical application, but the described results seem to justify the conclusion that the hot aqueous solutions will, upon further study of concentrations and circulation, offer a useful set of coolants to bridge the gap between water and oils at atmospheric temperatures, at least for the hardening of small steel parts. 


\begin{tabular}{|c|c|c|c|c|c|c|c|}
\hline & 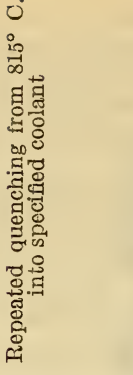 & & & 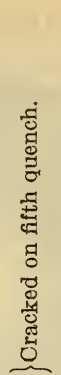 & 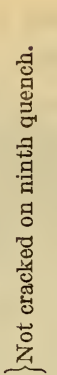 & 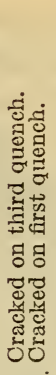 & 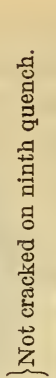 \\
\hline \multirow{2}{*}{ 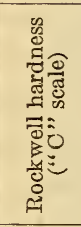 } & 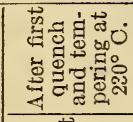 & 은요 & 아역 & ชิธี & 政 & $\overrightarrow{20}-\overrightarrow{0}$ & 요을 \\
\hline & 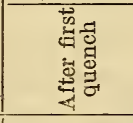 & 동ำ & ชิ & is is & $\underset{1020}{1020}$ & ำ 18 & 슨 \\
\hline \multirow{2}{*}{ 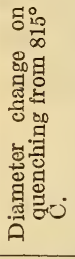 } & $\begin{array}{l}0 \\
\text { 解 } \\
\frac{5}{4}\end{array}$ & 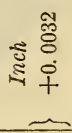 & $\begin{array}{l}8 \\
\delta \\
+ \\
+\end{array}$ & $\begin{array}{r}\stackrel{\text { No }}{8} \\
+\end{array}$ & $\begin{array}{r}0 \\
0 \\
0 \\
+ \\
+\end{array}$ & & $\begin{array}{l}0 \\
\dot{8} \\
+\end{array}$ \\
\hline & 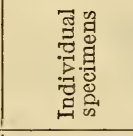 & 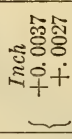 & 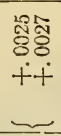 & 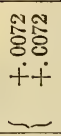 & $\begin{array}{l}80 \\
080 \\
08 \\
++1 \\
+ \\
+\end{array}$ & & $\begin{array}{l}\text { 드ㅇㅛㅛ } \\
+\dot{+} \\
+\dot{+}\end{array}$ \\
\hline \multirow{2}{*}{ 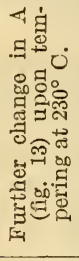 } & 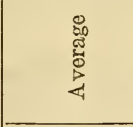 & 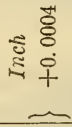 & $\begin{array}{r}8 \\
8 \\
+ \\
+\end{array}$ & $\begin{array}{r}80 \\
8 \\
+ \\
+\end{array}$ & $\begin{array}{l}8 \\
8 \\
+ \\
+ \\
\end{array}$ & $\begin{array}{l}\overrightarrow{8} \\
+\end{array}$ & $\begin{array}{l}80 \\
8 \\
+\end{array}$ \\
\hline & 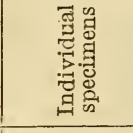 & 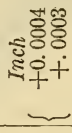 & $\begin{array}{l}80 \\
80 \\
++\end{array}$ & $\begin{array}{l}8 \overrightarrow{8} \\
808 \\
\dot{+}+\end{array}$ & 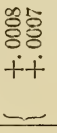 & $\begin{array}{l}\overrightarrow{8} \\
+ \\
+\end{array}$ & $\begin{array}{l}200 \\
80 \\
+10 \\
++1 \\
\end{array}$ \\
\hline \multirow{2}{*}{ 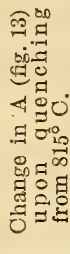 } & 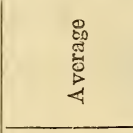 & 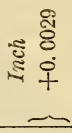 & $\begin{array}{r}8 \\
8 \\
+ \\
+\end{array}$ & $\begin{array}{l}0 \\
\stackrel{0}{0} \\
+ \\
+\end{array}$ & $\begin{array}{l}\text { स्त } \\
0 \\
+ \\
+\end{array}$ & $\begin{array}{l:}0 \\
\delta \\
0\end{array}$ & $\begin{array}{l}8 \\
8 \\
+ \\
+\end{array}$ \\
\hline & 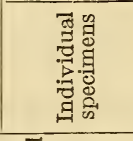 & 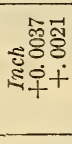 & $\begin{array}{l}\text { 휴융 } \\
\text { i+ }\end{array}$ & $\begin{array}{l}82 \\
\text { 웡 } \\
++\end{array}$ & 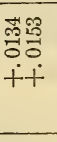 & $\begin{array}{l}\text { षั } \\
\text { के } \\
+=\end{array}$ & $\begin{array}{l}\text { 융 } \\
\text { o. } \\
+\dot{+}\end{array}$ \\
\hline \multicolumn{2}{|c|}{ 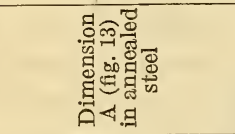 } & \multicolumn{2}{|c|}{ 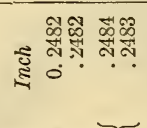 } & 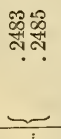 & 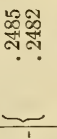 & 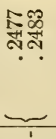 & 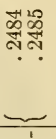 \\
\hline \multicolumn{2}{|r|}{ 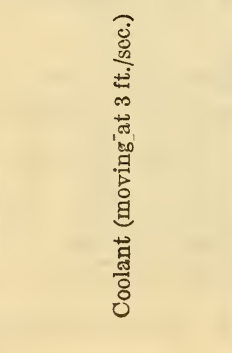 } & 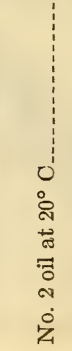 & 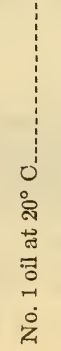 & 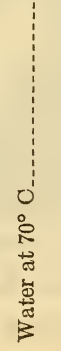 & 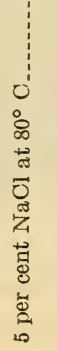 & 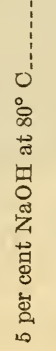 & 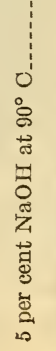 \\
\hline
\end{tabular}




\section{SUMMARY}

1. Surface and center cooling curves were obtained on cylinders of 0.96 per cent carbon steel, one-half inch in diameter and 2 inches long, when quenched from $875^{\circ} \mathrm{C}$. into water, 5 per cent sodium hydroxide, 5 per cent sodium-chloride solutions, and two proprietary quenching oils at different temperatures between $20^{\circ}$ and $100^{\circ} \mathrm{C}$. The liquids were all moving at 3 feet per second and the cooling curves were correlated with the microstructures and the hardnesses produced in the cylinders.

2. Increase in temperature lowered the cooling speeds and increased the cooling times in water and the aqueous solutions, but the changes were smaller between $20^{\circ}$ and $60^{\circ} \mathrm{C}$. than between $60^{\circ}$ and $100^{\circ} \mathrm{C}$. Exactly opposite effects were produced in the center cooling by the two oils, but the changes were relatively small throughout the entire temperature range, $20^{\circ}$ to $100^{\circ} \mathrm{C}$.

3. As the temperature of the aqueous solutions approached the boiling point of water, the cooling at the surfaces of the cylinders became more irregular and the cooling rates at low temperatures around $200^{\circ}$ or $300^{\circ} \mathrm{C}$. became more rapid than at intermediate temperatures around $300^{\circ}$ to $500^{\circ} \mathrm{C}$. or at higher temperatures. However, smooth center cooling curves were obtained in water at temperatures up to and including $60^{\circ} \mathrm{C}$. or the 5 per cent solutions of sodium hydroxide or sodium chloride up to $80^{\circ} \mathrm{C}$.

4. These characteristics suggested the possibility of using the hot aqueous solutions to bridge the gap in cooling rates between water and the customary quenching oils at ordinary temperatures. The following were selected as the most promising of the liquids tested and are given in order of decrease in average cooling speeds (increase in center cooling times) over the range, $875^{\circ}$ to $200^{\circ}$ C.: 5 per cent $\mathrm{NaOH}$ at $20^{\circ} \mathrm{C}$.; 5 per cent $\mathrm{NaCl}$ at $20^{\circ} \mathrm{C}$.; water at $20^{\circ} \mathrm{C}$; 5 per cent $\mathrm{NaOH}$ at $60^{\circ} \mathrm{C}$.; 5 per cent $\mathrm{NaCl}$ at $60^{\circ} \mathrm{C}$.; water at $60^{\circ} \mathrm{C}$.; 5 per cent $\mathrm{NaOH}$ at $80^{\circ} \mathrm{C}$; 5 per cent $\mathrm{NaOH}$ at $85^{\circ}$ or $90^{\circ} \mathrm{C}$.; the two proprietary oils at $20^{\circ}$ to $100^{\circ} \mathrm{C}$.

5. Not all of these would be classed as good coolants for practical heat treatment and substitutions or additions can be made from the group studied, but experimental application of some of the hot aqueous solutions in the quenching of medium carbon steel and nickelchromium steel tensile test bars and a limited study of the dimensional changes and cracking of carbon-chromium steel gages of special form showed promising possibilities. The results seem to justify the view that the hot aqueous solutions should, with further study of concentrations and circulation, ultimately provide a useful set of coolants having speeds intermediate between water and oils at atmospheric temperatures, at least in the hardening of small pieces of steel. 


\section{ACKNOWLEDGMENTS}

Acknowledgment is made to $\mathrm{H}$. K. Herschman, associate metallurgist, for the micrographs; to H. A. Bright, associate chemist, for the chemical analysis of the steels; and to H. T. Kennedy and T. S. Sly, of the oil section, for the test data on the two quenching oils.

Washington, April 11, 1929. 